\title{
Improving School Literacy Through Reading Friday Program
}

\author{
Markhamah $^{1}$, Harun Joko Prayitno ${ }^{2}$, Suyatmini ${ }^{3}$, Triyanto ${ }^{4}$ \\ \{ markhamah@ums.ac.id $^{1}, \underline{\text { harun.prayitno@ums.ac.id }}{ }^{2}$ sut197@ums.ac.id ${ }^{3}$, tryanto@gmail.com $\left.{ }^{4}\right\}$ \\ 1,2,3,4 Education Administration Study, Graduate School, Universitas Muhammadiyah Surakarta, \\ Indonesia
}

\begin{abstract}
This study aims to describe Reading Friday program and its contribution in improving school literacy. The object of this research is Reading Friday program in Tasikmadu Junior High School in Karanganyar, Central Java. Data collection uses observation, interview, and documentation techniques. Data analysis is performed using an interactive model, during collection and after completion of data collection. The results of the study indicate that Reading Friday is a program carried out to increase the literacy of students, which was held on third Friday of each month, can be either in class or outdoor, overseen and assessed by teachers through reading notes in assignment books. Reading Friday program contributes in improving school literacy through four ways: (1) increasing students' reading interest and empowering library, (2) increasing students' productivity in school creative writings/art (3) increasing students' seriousness in learning and their test scores (4) helping students understand school subjects easier.
\end{abstract}

Keywords: Reading Friday, school literacy, reading motivation.

\section{Introduction}

"Once you have an innovation culture, even those who are not scientists or engineers poets, actors, journalists - they, as communities, embrace the meaning of what it is to be scientifically literate. They embrace the concept of an innovation culture. They vote in ways that promote it. They don't fight science and they don't fight technology." Neil deGrasse Tyson (astrophysicist, author, science communicator).

It was the very same innovation culture that drove Indonesian Minister of Education and Culture to sign Regulation No 23 of 2015, which kickstarted the National Literacy Program, a program that requires students to use 15 minutes of class time to read in effort to bring forth their full potential through literacy.

Tasikmadu Junior High School is founded in 1969 and located in Tasikmadu sub-district, Karanganyar regency, Central Java province; and as any other public school it is obliged to obey the regulation above. As an answer, it initiated a new program called Reading Friday in 2016.

A study on the program is important so that educators from various schools can compare notes on various approaches and their results in relationship with the National Literacy Program. This research will observe and describe the details of the program and whether or not it actually helps in improving school literacy. 


\section{Method of research}

This research classifies as qualitative research. Data collection techniques are carried out by interviews, observations, and documentations. Object of research is Reading Friday program in Tasikmadu Junior High School, Karanganyar, Central Java.

According to Sugiyono (2010: 231), interview is a meeting of two people to exchange information and ideas through question and answer, so that meaning can be constructed in a particular topic [4]. In-depth interviews can be carried out at the right time and context that are deemed appropriate to obtain detailed and in-depth data, and can be done many times according to the needs of the researcher (Sumardjoko, 2015: 20) [5]. Interviews were conducted to explore data on planning the "Reading Friday" program and implementation. Respondents interviewed were the principal, the assistant teacher, and the Indonesian teacher. Observations were made during the "Reading Friday" activity and the results of their activities in the form of writing/student work which were displayed in the space provided. In general, the interviews were carried out in 2018.

According to Sugiyono (2010: 239), document is a record of events that have passed in the form of writing, pictures, or monumental works from someone [4]. Documentations taken as data in this study are the work of students, such as poetry and short stories. Other documents include a list of library book borrowers and library visitor lists, the activity program book, library book borrower rules, library regulations, and photos of school literacy activities.

The data validity testing technique is used to prove whether the research carried out is truly scientific research and to increase the degree of trust in the data obtained. Data validity testing technique is an important concept that is influenced by the concept of validity, reliability, and adjusted to the demands of knowledge, criteria, and paradigm itself (Moleong, 2009: 321) [6]. The validity of the data in this study was tested by a credibility test carried out by triangulation. The triangulation used in this study was source and technique triangulations.

Data analysis is carried out with interactive model, at the time of data collection and after completion of data collection. Activities in qualitative data analysis are carried out interactively and continuously to completion (Milles and Huberman, in Sugiyono, 2010: 337) [4]. The component of analysis consists of data reduction, data presentation, and drawing conclusions.

\section{Research result}

The result of this study describes the Reading Friday program and its contribution in improving school literacy.

\subsection{Reading Friday Program}

Based on observations made by researchers, Reading Friday program is carried out every third Friday of each month before the lesson begins, with the aim of increasing literacy in reading and writing or improving school literacy in general.

In this activity, all students read according to their interests. After reading, students write various tasks according to the direction of teachers from various fields of study. In addition to writing, there is a teacher who asks students to memorize the contents of the book they are reading. 
The activity can be held in classes or outdoor, based on monthly schedule. In class Reading Friday is held in October, November, December and May, June. The outdoor Reading Friday is held in July, August, September and January, February, March.

In the program, students are given the freedom to read non-learning books borrowed from the library or provided by the program and guided by teachers who teach in the first hour. In activities outside the classroom, students are given the freedom to read any reading materials they like such as newspapers, magazines, story books, or other fiction books and are guided by their respective homeroom teachers.

Assessments in Reading Friday program is performed by homeroom teachers. Under the guidance of teachers, students must make a brief note about what they read in the special assignment book and later collected in their respective classes.

Teachers act as guides, directors, and companions when students are reading. In addition, teachers can also provide examples of reading activity. Based on observation, there are teachers who are seen reading and teachers who give direction to the students.

\subsection{Contribution of Reading Friday in Improving School Literacy}

From the results of interviews and data analysis, it can be observed that Reading Friday program contributes in improving school literacy through four ways: (1) increasing students' reading interest and empowering library, (2) increasing students' productivity in school creative writings/art (3) increasing students' seriousness in learning and their test scores (4) helping students understand school subjects easier.

Increasing students' reading interest and empowering library. The increase of students' interest in reading as an effect of Reading Friday is mentioned the following interview excerpt.

"Every teacher has responsibility for their students how to have a passion for learning. One of the contributions from the Reading Friday program is to grow students' interest in reading in order to increase their knowledge and improve their academic achievement, with various variations and learning models" (Interview with YN, April 12, 2018)

The Reading Friday activity also empower library functions, which improvement can be identified by the increasing number of visitors to the library to borrow and read books. A few interviews noted the increase:

"School literacy activities are very important as an effort to improve the quality of human resources. The Reading Friday activity proved to be able to contribute positively to our students to foster interest in reading as a provision to understand their knowledge. After the Friday Reading program, the level of student visits to the library increased, and the achievement of academic values also increased. "(Interview with TW, 11 April 2018).

Similar observation was stated by $\mathrm{N}$, the Vice Headmaster of Curriculum. "After the Reading Friday program started in 2016/2017 the impact is very significant as it is evident from the interest of students to borrow books in the library increases, the level of visits to the library also increases, students' literacy creativity also increases. This is evidenced by the writings of students displayed on school wall magazines, including poems, short stories, as well as slogans with educational themes." (Interview on 11 April 2018).

This is in accordance with the following statement from the library head. "After the Reading Friday program, there is indeed an increase in student visits to the library, there are individuals and class groups. The use of library facilities depends on how the teacher can 
direct students to increase students' interest in school literacy activities. But unfortunately not all teachers make use of the school library facilities."(Interview on 12 April 2018).

In addition to being able to be noted from interviews, it can also be seen from the increase in the number of students visiting the library and the increase in book borrowers, before and after Reading Friday as seen in Table 1.

Table 1.The number of students visiting and borrowing book at the library

\begin{tabular}{l|ll}
\hline Indicator & Before Reading Friday & After Reading Friday \\
\hline $\begin{array}{l}\text { Student } \\
\text { visits }\end{array}$ & $\begin{array}{l}15-20 \text { students / week } \\
61 \text { students / month } \\
\text { average }\end{array}$ & $\begin{array}{l}\text { 30-50 students / week } \\
120 \text { students / month } \\
\text { average }\end{array}$ \\
\hline Book \\
borrowing & $\begin{array}{l}10 \text { students / week } \\
\text { average } \\
40 \text { students / month } \\
\text { average }\end{array}$ & $\begin{array}{l}\text { 20 students / week } \\
\text { average } \\
80 \text { students / week } \\
\text { average }\end{array}$ \\
\hline
\end{tabular}

From the table above, it can be seen that the number of students visiting libraries and book borrowers is increased by around $100 \%$ after Reading Friday program was initiated.

Increasing students' productivity in school creative works. Suharyanto, Vice Headmaster in Student Affairs, stated how Reading Friday program has improved the creativity of students.

"In the past year after school literacy activities initiated, especially Reading Friday, it turned out that students' creativity grew and there seemed to be an increase compared to before the program began. I try to explore the potential of students' through the tasks that I have given that relate to the ability to read and write in the form of work displayed in the school wall magazine" (interview dated 12 July 2018).

Before Friday Reading program was initiated, there were only 5 works of writing on school wall magazine. After the program started, the works on display in the wall magazine reached 38, with details as seen on Table 2.

Table 2.Data on student creative works

\begin{tabular}{l|lll}
\hline No & Form & Type & Number \\
\hline 1 & Poem & Old Poem & 7 \\
& & New Poem & 10 \\
2 & Rhyme & & 6 \\
3 & Short Story & 6 \\
4 & Free Writing & 5 \\
5 & Painting & 4 \\
\hline & Total & 38 \\
\hline
\end{tabular}

Increasing students' seriousness in learning and their test scores. The Vice Headmaster in Curriculum stated that after Reading Friday was initiated, an increase in the seriousness of students in learning is observed. 
"The contribution of the Reading Friday program to students' interest in reading is indeed very visible, with guidance and direction from teachers, now they have begun to have seriousness in understanding each subject matter given and influencing their academic value improvement." (Interview dated July 12, 2018)

The increase in seriousness in learning is also supported by the level of achievement before and after Reading Friday; shown in Table 3.

Table 3.Improvement of student academic achievements

\begin{tabular}{|c|c|c|}
\hline Indicator & $\begin{array}{l}\text { Academic achievement } \\
\text { before }\end{array}$ & $\begin{array}{c}\text { Academic achievement } \\
\text { after }\end{array}$ \\
\hline $\begin{array}{l}\text { Daily } \\
\text { test }\end{array}$ & $\begin{array}{l}\text { Only } 10 \text { out of } 32 \\
\text { students score above } \\
\text { competence standard }\end{array}$ & $\begin{array}{l}25 \text { out of } 32 \text { students } \\
\text { score above competence } \\
\text { standard }\end{array}$ \\
\hline
\end{tabular}

If observed in terms of the percentage increase in academic achievement, Reading Friday increased the scores by $150 \%$, a very significant increase in academic performance.

The improvement of test scores is also mentioned by Yuliati Poncorini in an interview. "The contribution of the Reading Friday program to students' reading interest is indeed very visible, with the direction and guidance of teachers, now they have begun to have seriousness in understanding each subject matter given and having an impact on their daily test scores." 2018).

Helping students understand school subjects. Reading Friday program also helps students to understand and deepen their school subjects material, as conveyed by NAD and BS, class VIII students.

"The Reading Friday program benefited us because we were motivated by the teacher to be more enthusiastic in literacy activities, by reading, our knowledge increased and made it easier to understand the subject matter given by the teachers." (Interview with NAD, April 12, 2018).

"The Reading Friday program is held every third week, even if only once a week, but we feel the benefits. With the guidance of the teacher, we are directed to read useful books that help deepen the subject matter." (Interview on 12 April 2018)

The evidence above proves that the benefit of Reading Friday program is also felt by the students as well, not only the school and teachers.

\section{Discussion}

This section discusses the results of this research in comparison with other relevant studies; the similarity, difference, and other details.

The results of Wandasari (2017) are partially similar to the results of this study [7]. The difference is that Wandasari sees the results in focus of improving the character of students. The results obtained from the school literacy activities were that the character of students began to form, including responsibility, discipline, cooperation, and curiosity began to increase. Meanwhile, the school literacy activities in this study increase the demand for reading, academic achievement, the number of library visitors, and the increase in the number of book borrowers in the school library. 
Similar research has been carried out by Christanti (2015) [8]. The results that distinguish it from this research and other studies are the types of books used. On average students only read one book in a month, and most of them are literary books, fiction and novel. Christanti conveyed input from students and teachers interviewed. Student input is the time to carry out reading should be extended with the design of activities that are not boring. Whereas the teachers suggested that technical instructions and guidelines for evaluating activities be standardized.

Lesley (2011) focuses on students' reading motivation [9]. Similar to this research, it finds school activities can foster students' reading motivation. The difference, Lesley's research did not find school activities that could increase knowledge and increase the number of library visitors, while this research did.

This study is in line with the research conducted by Lynch and Ferguson (2010) [10]. Both find activities that can improve school literacy. The difference is that Lynch and Ferguson did not state any activities that could increase knowledge and increase the number of library visitors. However, this study found school activities that can.

The results of Stevens (2006) are similar to this study [11]. Stevens states that students understand what they read, they are connected to stories, they are motivated, interested and they are actively involved in learning and enjoying every minute. There is a transfer of maturity on students aged 10-15 years who began to develop self-confidence obtained from students who are older by entering into their social groups. Young students are more motivated to develop their literacy skills

Literacy activities are not only reviewed from the implementation of activities, the types of activities, but also from who plays a role in literacy activities and how they are intended, as studied by Shohibah (2015) [12]. The results show that the role of parents and their environment in fostering literacy, namely reading interest, can be seen from the provision of facilities. In addition, parents are directly involved in the literacy activities. Thus, there is interaction between students and parents. So, families familiarize their kids with literacy habits.

Widyawati (2017) [13] also states something similar to what was conveyed by Shohibah. The difference is that Widyawati shows that those who play a role in growing literacy culture are principals, teachers, and librarians; principals have the role of making policies or programs to improve literacy culture in schools, teachers make learning programs and motivate students to love reading, and librarians provide good circulation services and library references.

Lynch and Ferguson (2010) states that the role of the teachers, obstacles to implementation effective literacy, and solutions to overcome obstacles are three things that are reflected in school literacy activities [10]. Jetton et al. (2008) stated that universities also have a role in increasing youth literacy in schools that are under their guidance [14].

Literacy activities can help someone to improve their achievements or success, as Wen Ma (2009) examined [15]. His research focuses on Chinese students who were high achievers in a relatively short time. One factor that helps is socio-cultural capital, which can help overcome the challenges of education and socialization. Another factor is literacy, where they are no stranger to books and reading culture. On every occasion the Chinese student takes the time to read. Nonetheless, the results of testing the influence between after-school literacy activities and graduating/failing students conducted by Liying et al. (2009) [16] showed a difference with the research of Wen Ma (2009). Liying states a relatively small but complex relationship between the performance of different student group tests on literacy tests, reading, writing activities after school. 
Sutrisna (2018) states that online literacy can help develop iterative activities for students by using the Google Classroom application [17]. The advantages of this application are: (1) ease of accessing applications, (2) allowing lecturers to send reading assignments or literacy materials to all students quickly, (3) lecturers can use this application for discussion rooms, (4) lecturers can instruct, assign, and discuss with students online at the same time simultaneously.

\section{Conclusion}

Reading Friday is defined as 15 minutes reading activity for students with the aim of increasing the school literacy. The activity was held on third Friday of each month. It can be held in class or outdoor based on monthly schedule. Teachers oversee this program and provide direction and guidance plus assessing the results through notes submitted by students in a special assignment books.

Reading Friday program contributes in improving school literacy through four ways: (1) increasing students' reading interest and empowering library, (2) increasing students' productivity in creative writings and art (3) increasing students' seriousness in learning and their test scores (4) helping students understand school subjects easier.

Reading Friday is proven as an effective program to increase school literacy and this research suggest schools in general to initiate similar programs and innovate further.

\section{References}

[1]Pratiwi, et al, 2016. Panduan Gerakan Literasi Sekolah di SMP. Jakarta: Direktorat Jenderal Pendidikan Dasar dan Menengah Kementrian Pendidikan dan Kebudayaan

[2]Kamus Besar Bahasa Indonesia Online. 2019. http://kbb.kbbi.kemdikbud.go.id, accessed on 26 June 2019, 15.00 .

[3]Axford. 2009. Scaffolding Literacy: An integrated and sequential approach to teaching, reading, spelling and writing. Australia, ACER Press.

[4]Sugiono. 2010. Metode Penelitian Pendidikan (Pendekatan Kuantitatif, Kualitatif dan R\&D). Bandung: Alfabeta.

[5]Sumardjoko, Bambang. 2015. Metodologi Penelitian Kualitatif. Surakarta: Universitas Muhammadiyah Surakarta.

[6]Moleong, Lexy J. 2009. Metodologi Penelitian Kualitatif, Bandung: PT.Remaja Rosda Karya.

[7]Wandasari, Y. 2017. "Implementasi Gerakan Literasi Sekolah (GLS) sebagai Pembentuk Pendidikan Karakter”. Jurnal Manajemen, Kepemimpinan, dan Supervisi Pendidikan. 2 (1). pp. 1222.

[8]Christanti. 2015. Gerakan Budaya Literasi di SMAN II Sidoarjo. https://publikasi.ums.a.id/bitstream/handle/11617/8917/i18.pdf.

[9]Lesley, Mellinee. 2011. Understanding Resistance: Preservice Teachers Discourse Models of Struggling Readers and School Literacy Tasks. Journal of Adolescent \& Adult Literacy. Vol.55, No.1 pp. 25-34. http://www.jstor.org/stable/41309644

[10]Lynch, Jaqueline, and Kristen Ferguson. 2010. Reflections of Elementary School Literacy Coaches on Practice: Roles and Perspective. Canada Journal of Education/Revue Canadienne de l'education, Vol. 33, No. 1, pp. 199-227. http://www.jstor.org/stable/canajeducrevucan.33.1.199

[11]Stevens, Robert J. 2006. Integrated Middle School Literacy Intruction. Middle School Journal, Vol. 38, No. 1, pp. 13-19. http://www.jstor.org/stable/23024469

[12]Shohibah. 2015. Peran Orang Tua Dalam Mengembangkan Budaya Literasi Pada Anak Usia Sekolah Dasar. 
[13]Widyawati. 2017. Strategi Sekolah Dalam Meningkatkan Budaya Literasi Di SMA Muhammadiyah 2 Sidoarjo.

[14]Jetton, Tamara L, Mary Beth Cancienne, and Brenda Greever. 2008. The Evolving Roles of Faculty Learning Communities: A University/High School Literacy. Theory Into Practice, vol. 47 No.4 Collaborative Learning Communities in School, pp. 327-335. http://www.jstor.org/stable/40071562

[15]Wen Ma 2009. Beyond Learning Literacy at School: One Chinese Adolescent's Educational Journey, American Secondary Education, Vol. 37, No.3, pp. 52-69. http://www.jstor.org/stable/41406316

[16]Liying Cheng, Don A. Klinger, and Ying Zheng. 2009. Examining Students After School Literacy Activities and Their Literacy Performance on The Ontaro Secondary School Literacy Test. Canadian Journal of Education/ Revue Canadienne de l'education, Vol. 32, No.1, pp. 118-148. http://www.jstor,org/stable/canajeducrevucan.32.1.118

[17]Sutrisna, Dede. 2018. "Meningkatkan Kemampuan Literasi Mahasiswa Menggunakan Google Classroom". FON Jurna Pendidikan Bahasa dan Sastra Indonesia. Vol. 13 No. 2 2018. pp. 69-78. 